\title{
Farmers' Perception on the Effect of Rainfall Variability on Rice Yield in Dadin-Kowa of Gombe, Gombe State
}

\author{
Bachama Boyi Noel ${ }^{1}$, Audu Haruna Omar ${ }^{1}$, Ibrahim Ahmed Kawu ${ }^{2}$, Matai Emon Parmaina ${ }^{4,}$, \\ Adamu Muhammad Kamaludeen ${ }^{1}$, Tarki Sadiq Kubmuto ${ }^{3}$ \\ ${ }^{1}$ Department Geography, Faculty of Humanities Management and Social Sciences, Federal University of Kashere, Kashere, Nigeria \\ ${ }^{2}$ Department of Soil Science, Federal University of Kashere, Kashere, Nigeria \\ ${ }^{3}$ Department of Agricultural Economics, Federal University of Kashere, Kashere, Nigeria \\ ${ }^{4}$ Department of Horticultural Technology, Federal Collage of Horticulture, Dadin Kowa, Nigeria
}

Email address:

mongareenho3@gmail.com (M. E. Parmaina)

${ }^{*}$ Corresponding author

\section{To cite this article:}

Bachama Boyi Noel, Audu Haruna Omar, Ibrahim Ahmed Kawu, Matai Emon Parmaina, Adamu Muhammad Kamaludeen, Tarki Sadiq Kubmuto. Farmers' Perception on the Effect of Rainfall Variability on Rice Yield in Dadin-Kowa of Gombe, Gombe State. International Journal of Archaeology. Vol. 8, No. 2, 2019, pp. 15-21. doi: 10.11648/j.ija.20200802.11

Received: September 22, 2019; Accepted: October 24, 2019; Published: September 17, 2020

\begin{abstract}
This work examines famers' perception on the effect of rainfall variability on rice yield in Dadin-kowa, Yamaltu Deba Local Government Area of Gombe State. Nigeria. Data for the study were collected via questionnaire survey of 60 respondents and it also covered and relates with daily rainfall data for a period of Seventeen (17) years, 2001 to 2017 from Upper Benue River Basin Dadin-kowa Meteorological Centre. Frequency table and percentages was used to access the Indepth knowledge and the perceived effects of climate change, rainfall variability to be précised, on rice production. While the analysis using Cumulative Rainfall Model clearly demonstrates delay in onset of rainy season, early cessation of rainy season and shortening of the length of hydrological growing season. The result further reveals $30^{\text {th }}$ May as the onset mean date, the cessation mean date is $12^{\text {th }}$ October and hydrological growing season is having a mean of 137 days. Farmers make sequential decision: Adjusting planting timing in response to delays in the onset of rainy season while changing crop variety responding to delay in the end of previous year's rainy season. The findings of the study show that the decrease in yield of rice is the immediate impacts of rainfall variability. Thus a study understanding farmers' perception on the effects of rainfall variability on rice yield can prove extremely valuable.
\end{abstract}

Keywords: Onset, Cessation, Hydrological Growing Season, Farmers Perception

\section{Introduction}

Variability in global climate and change are evident with enormous impacts, which vary across locations and socioeconomic features. Reports on empirical observations and climate models indicate that global climate have been changing over the past 100 years and will likely change more rapidly in the future [6]. The severities of impacts of climate change on our ecosystems are already evident and affect food security of humankind [7]. Agriculture, being central to livelihoods in Africa, is considerably vulnerable to variability in climate and change [8]. Global agriculture in the $21^{\text {st }}$ century has significantly been affected by climate change and future impacts are projected to worsen as the temperature continues to rise and precipitation becomes more unreliable [9]. There was an increase in intensity and frequency of heavy precipitation events in the last 50 years and the spatial pattern of the rainfall is likely to change, with rise in number and intensity of extreme rainfall events which adversely impact the natural resources on which majority of the population is dependent [10]. Hence, there is need to recognize the enormous impacts of variability in global climate and change on agriculture. Impacts of variability in global climate and change on rainfall affect farmers in many regions, countries and developing countries including Africa. In India, the meteorological records indicate rise in the mean 
annual surface air temperature by $0.4^{\circ} \mathrm{C}$ with not much variations in absolute rainfall [10]. Developing countries especially in Africa are highly susceptible to the impacts [1116] and the poor already struggle to cope [17]. The poor in Africa, particularly peasant farmers, are highly vulnerable to climatic and environmental hazards as their options for diversifying their resources and income sources are limited [9]. Thus, CVC affect agricultural production of farmers in Africa as well as Nigeria. Nigerian economy from past decades depends on the agricultural sector, which is reputed as the mainstay of the economy and the key driver for growth and development [18]. Yet, Nigeria is experiencing adverse climate conditions with negative impacts on welfare of millions of people, persistent droughts and flooding, off season rains and dry spells which have sent growing seasons out of track [19].

Agriculture will still remain the foreseeable future, the linchpin of the economy and the primary source of ensuring food security at local, national as well as global scale. Hence any threats to its optimal productivity need to be handled with all amount of seriousness [1]. In particular, the evidence as reflected in locally tailored solutions often provided by local farmers in mitigating agricultural challenges, it will be very true that cultural norms and values holds potential in raising or reducing the productivity of small-scale rice farmers and consequently improve or depreciate their livelihood respectively. Thus, The need to harmonized both climate change which constantly and continuously threatens agricultural productivity through the effects of higher temperature, more frequent droughts and flooding as well as rise in sea level that threatens rice production, And the Status quo of rice being a staple food capable of reducing hunger and for ensuring human health and nutritional food Security, rice productivity needs to be profitable while Farmers' Perception on Climate Change needs to be void of Dogmatic and Ancestral beliefs. The impact of global climatic change on agriculture, and especially precipitation and temperature variability (PTV), has recently become an issue of increasing importance. Rice production in Nigeria is dominated by smallholders' farmers who use traditional methods that are characterized with problems of low productivity [4]. However, relatively little is known about how cultural values and norms as reflected in local farmer's perception as well as in decision making will interact with climate change to sustain or erode agricultural productivity. [3] reported that local farmers are seriously concerned about rainfall variations because of the impact on food security, accessibility and utilization. Thus, it becomes imperative therefore, to investigate and know the indepth knowledge of farmers on the impact of climate on rice production for ease of adaptation and to provide for further improvement in productivity.

Rice farmers have been witnessing heavy downpours due to intense rains as a result of variability in timing and amount of rainfall caused by climate change [23]. The degree and intensity which rains are experienced in recent times is far beyond what farmers are familiar and can grapple with in order to remain productive [23].

The focus of this study is centered on rainfall because rice production system in Nigeria is mainly rain-fed. Rain water supply is the limiting factor to the growth and production of rice in Nigeria as reflected by geographical distribution of rice-growing areas over region of heavy rainfall. Some of the major problems associated with rice production include drought, flooding, salt stress and extreme temperatures all of which are expected to worsen with climate change. [23]. Drastic changes in rainfall patterns and rise in temperatures will introduce unfavorable growing conditions into the cropping calendars. These changes modify growing seasons which subsequently reduce rice productivity [24].

\section{Methodology}

\subsection{Study Area}

The Dadin-Kowa is in Yamaltu Local Government area of Gombe State in the north east of Nigeria. Dadin-kowa town is located between Latitudes $10^{\circ} 19^{\prime} 19^{\prime \prime} \mathrm{N}$ and $10.32194^{\circ} \mathrm{N}$; Longitude $11^{\circ} 28^{\prime} 54^{\prime \prime} \mathrm{E}$ and $11.48167^{\circ} \mathrm{E}$ [25]. It shares common boundary with Akko L. G. A in the South and West, Yamatu-Deda to the East and Kwami to the North. Dadinkowa has an altitude of about 370 meters above sea level [25]. It is a residential and commercial area with such amenities as schools, Motor Park, market etc.

The study area is characterized by two distinct climates, the dry season (November-March) and the rainy season (April-October) with an average rainfall of $850 \mathrm{~mm}$ and the mean annual temperature is about $32^{\circ} \mathrm{C}$, [26]. The dry season comes with the north eastern trade wind over the region originating from Sahara belt, the wind is dry and dust laden accompanied by low pressure system. The wet season comes with the south-westerly wind which is moisture laden ad originates from high pressure zone over the Atlantic Ocean to the low pressure zone over the Sahara.

\subsubsection{Relief}

The relief of the Dadin-kowa town ranges between $650 \mathrm{~m}$ in the western part to $370 \mathrm{~m}$ in the eastern parts [27]. The area in the eastern parts is dominated by flat terrain with hills of sandstones in the western part of the study area.

\subsubsection{Soil}

The soil of the study has a sandy clay loam texture, slightly acidic, low in major nutrients and moderate in available soil moisture content [26]. This is typical of savanna soils that are highly depleted with poor structure that requires close monitoring and adoption of best soil management practices to maintain its productivity [26].

\subsection{Source of Data}

The type of data required for this research include Annual daily rainfall data sourced from Upper Benue River Basin Development Authority Dadin-Kowa metrological station, similarly Perception of farmers toward rainfall variability and how it affect rice yield are sourced from administered questionnaire. Data for the research will be sourced from two main sources: primary source and secondary source. 


\subsubsection{Primary Data}

The primary data for this study was obtained by administering questionnaire to 60 rice farmers in the study area.

\subsubsection{Secondary Data}

Daily rainfall data for seventeen years $(2001-2017)$ was collected from the Upper Benue River Basin Development Authority office in Dadinkowa, Gombe State, other data and information on the research was obtained from books, dailies, dissertation, journals, thesis, websites and other public media relevant to the study. This help to provide facts for the research being undertaken.

\subsection{Computational and Analytical Techniques}

The rainfall onset and cessation dates, as well as the length of the rainy season were determined by adopting the percentage mean cumulative rainfall method. The method has the advantage of directly using the rainfall data or rainy days, rather than inferring the rainfall amount from other related parameters, making it appropriate for this study.

\subsubsection{Plotting Rainfall Ogive}

Firstly, the daily mean rainfall amount or rainy days from the entire data record (2001-2017) are calculated. For the determination of onset, cessation and length of the rainy season (LRS) or Hydrological Growing Season (HGS) in the study area five-day (pentad) were used to compute running sum for each year from 2001-20017. For example, the first five days are designated by " $Z 1$ " and the second

"Z2", third "Z3" to the last "Z73"Where "Z73" = number of pentad in $365 / 5$

$365=$ number of days in a year

$5=$ pentad

Pentad $=\mathrm{P}$

$\mathrm{P} 1=\mathrm{Z} 1$

$\mathrm{P} 2=(\mathrm{P} 1+\mathrm{Z} 2)$

$\mathrm{P} 3=(\mathrm{P} 72+\mathrm{P} 73)$

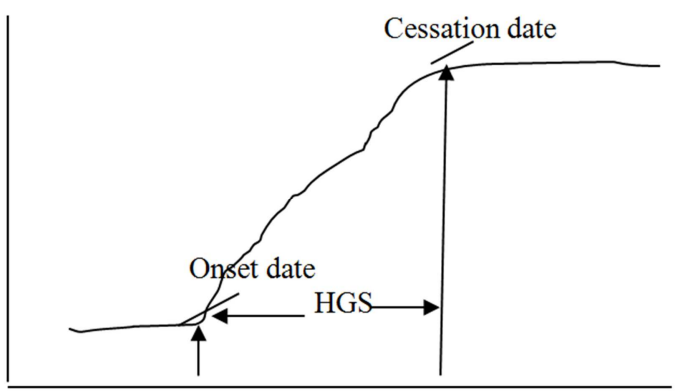

Figure 1. Cumulative frequency graphs of onset, cessation and HGS.

From the above computational procedure, cumulative ogive (cumulative frequencies of rainfall curves) for each of the years were plotted and cessation dates were deduced from the lower and upper points of inflexions as shown below. This procedure was adopted for each year throughout the 17 years period in order to derive the mean onset and cessation dates and the deduction of the length of rainy season (LRS) or the hydrological growing season (HGS).

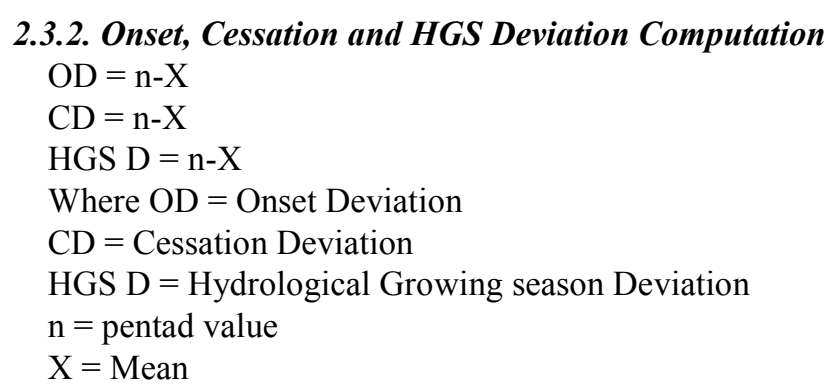

\subsection{Statistical Analysis of data Collected from Survey Questionnaire}

Frequency distribution table is used to ascertain the frequency (f) and percentage (\%) of the demographic characteristics of the respondents. This applies to Respondents awareness of changes in rainfall variation and perceived effect of rainfall variation on rice yield.

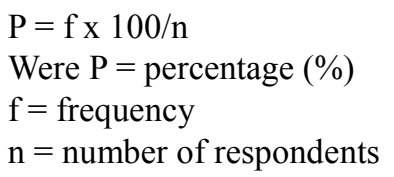

\subsection{Sampling Design and Questionnaire}

A multi-stage sampling technique is use to select respondents for the study. The first stage of selection entails purposive selection of 6 locations within the study area, in the second stage, the household will be chosen by random sampling technique. In order to fulfill the objectives of the intended study, a structured questionnaire survey is conducted, 60 respondents were sampled for the study. Data on respondent perception on the effect of rainfall were collected during the survey.

\section{Results and Discussion}

\subsection{Relationship Between Rice Yield and Respondent on Onset, Cessation in Dadin Kowa}

Result obtained from Table 1 reveals that, the onset of rainfall from 2001-2017 sway from 25-35 Pentade, resulting to $30^{\text {th }}$ may as the onset mean date. This means that rain fall is reliable for crop germination within the given Pentade and the mean date $30^{\text {th }}$ may, which is considered the onset of rainfall. The Pentade onset have a standard deviation of 3 (15) days, therefore implies that the onset of the rains can vary between $5^{\text {th }}$ May \pm 15 days on the lower limit to $24^{\text {th }}$ June \pm 15 days. The implication here is that any date of the onset of the rains that lie within these lower and upper limits of the onset is considered normal since it lies within the deviation of the onset. This also implies that crops planted above the deviation limit ( \pm 15 days) are vulnerable to critical dry spell that may affect both plant germination and establishment. 2008 and 2014 have earlier rainfall onsets, with 4 and 5 onset deviation value respectively. This is considered normal. Similarly, 2002 have a negative deviation of-5, this is considered abnormal. The implication of this finding is that agricultural production and other rainfall 
dependent livelihood activities will be highly affected since onset of rainfall is highly unpredictable and late. Plant preparation and planting calendar, which are dependent on the dates of onset of rainfall, will be difficult to select by farmers $[28,29]$. Predicted and confirmed shorter length of season that occurred in 2009. $12^{\text {th }}$ October as a findings of this work to be the cessation mean date justifies a very important outcome of this study were questionnaire results regarding the effects of the early cessation of rainy season on productivity growth of rice production are heterogeneous across farmers, depending on the financial capability and irrigation technology employed for those involved in both rain fed and irrigation agriculture.

\subsection{Relationship Between Rice Yield and Respondent on Hydrological Growing Season}

Judging by the computed Hydrological growing season (HGS) and days using cumulative rainfall model, the Hydrological growing season on average, extended over 6 months with a difference range of 10-55 days across the years. A shorter HGS of 110 days was observed in 2002 and 2013, while 2012 and 2014 were years with longer HGS of 165 days. It recorded a longer length of hydrological growing season for 2004, 2005, 2006, 2008, 2009, 2010, 2012 and 2014. Farmers identified these years for having met with crop unique optimum water requirement for proper crop germination and establishment consequently, higher yield. Respondents perceived effect of rainfall on rice yield. 95\% respondents affirmed the occurrence of reduction and fluctuation in rainfall pattern and subsequently changes in the length of Hydrological growing season as shown in Table 1. The result however is in conformity with the findings of Egbe et al who reported that respondents are aware of alterations in climate parameters and the regularity in their manifestations [2],. The result reveals a favourable disposition by $25.0 \%$ of the respondents of rainfall variability effects on rice yield. This indicates a positive impact on rice yield while $75.0 \%$ of the respondents were unfavorably disposed to the effects of rainfall variability on rice yield, indicating a negative impact on rice yield.

Table 1. Computed Onset, Cessation and Hydrological Growing Season (HGS) Pentadee, their Date and Deviation from 2001-2017.

\begin{tabular}{|c|c|c|c|c|c|c|c|c|c|}
\hline Year & $\begin{array}{l}\text { Pentade } \\
\text { Onset }\end{array}$ & $\begin{array}{l}\text { Onset } \\
\text { Deviation }\end{array}$ & Onset Date & $\begin{array}{l}\text { Pentadee } \\
\text { Cessation }\end{array}$ & $\begin{array}{l}\text { Cessation } \\
\text { Deviation }\end{array}$ & $\begin{array}{l}\text { Cessation } \\
\text { Date }\end{array}$ & $\begin{array}{l}\text { Pentadee } \\
\text { HGS }\end{array}$ & $\begin{array}{l}\text { HGS } \\
\text { Deviation }\end{array}$ & $\begin{array}{l}\text { HGS in } \\
\text { Days }\end{array}$ \\
\hline 2001 & 28 & 2 & $20^{\text {th }} / 5$ & 55 & 2 & $2^{\text {nd }} / 10$ & 27 & 1 & 135 \\
\hline 2002 & 35 & -5 & $24^{\text {th }} / 6$ & 57 & 0 & $12^{\text {th }} / 10$ & 22 & 6 & 110 \\
\hline 2003 & 32 & -2 & $9^{\text {th }} / 6$ & 58 & -1 & $17^{\mathrm{th} /} 10$ & 26 & 2 & 130 \\
\hline 2004 & 29 & 1 & $25^{\text {th }} / 5$ & 57 & 0 & $12^{\text {th }} / 10$ & 28 & 0 & 140 \\
\hline 2005 & 28 & 2 & $20^{\text {th }} / 5$ & 57 & 0 & $12^{\text {th }} / 10$ & 29 & -1 & 145 \\
\hline 2006 & 27 & 3 & $15^{\text {th }} / 5$ & 57 & 0 & $12^{\text {th }} / 10$ & 30 & -2 & 150 \\
\hline 2008 & 26 & 4 & $10^{\text {th }} / 5$ & 58 & -1 & $17^{\text {th }} / 10$ & 32 & -4 & 160 \\
\hline 2009 & 30 & 0 & $30^{\text {th }} / 5$ & 61 & -4 & $1^{\text {st }} / 11$ & 29 & -1 & 145 \\
\hline 2010 & 28 & 2 & $20^{\text {th }} / 5$ & 57 & 0 & $12^{\text {th }} / 10$ & 29 & -1 & 145 \\
\hline 2011 & 33 & -3 & $14^{\text {th }} / 6$ & 57 & 0 & $12^{\text {th }} / 10$ & 24 & 4 & 120 \\
\hline 2012 & 27 & 3 & $15^{\text {th }} / 5$ & 60 & -3 & $27^{\text {th }} / 10$ & 33 & -5 & 165 \\
\hline 2013 & 33 & -3 & $14^{\text {th }} / 5$ & 55 & 2 & $2^{\text {nd }} / 10$ & 22 & 6 & 110 \\
\hline 2014 & 25 & 5 & $5^{\text {th }} / 5$ & 58 & -1 & $17^{\text {th }} / 10$ & 33 & -5 & 165 \\
\hline 2016 & 31 & -1 & $4^{\text {th }} / 6$ & 57 & 0 & $12^{\text {th }} / 10$ & 26 & 2 & 130 \\
\hline 2017 & 30 & 0 & $30^{\text {th }} / 5$ & 56 & 1 & $7^{\text {th }} / 10$ & 26 & 2 & 130 \\
\hline MEAN & 30 & & $30^{\text {th }} / 5$ & 57 & & $12^{\text {th }} / 10$ & 28 & & 137 \\
\hline SD & 3 & & & 2 & & & 3 & & 17 \\
\hline
\end{tabular}

Source: Authors Field Data 2018.

\subsection{Demographic Characteristics of the Respondent in Dadin Kowa}

Demographic factors such as Sex, Age, Marital status, Educational level, Farming experience among others had been found to relate either negatively or positively with rice production in different context by researchers [20]. It is therefore a matter of concern to understand how demographic variables affect rice production.

\subsubsection{Gender}

Gender is a socio-cultural concept used to differentiate male and female. Gender plays a significance role in the agricultural sector where both men and women are involved in the agricultural value chain activities that complement each other [21]. The federal ministry of agriculture and rural development (FAMARD) reported that women account for $75 \%$ of the farming population, in Nigeria [22]. They are largely involve in the production, processing and trading of such as sorghum, maize, rice, cassava, pepper, vegetable, yam and oil. Men carry out tedious task such as land clearing and felling down of trees, gathering and burning of bush. A survey on gender involvement in crop production by Federal Ministry of Agriculture and Rural Development showed that male involvement in crop production declined while female involvement was on increase [22]. This has been associated with the increase in male out-migration to urban areas.

However, the findings of this research work reveal that male constitute $85 \%$ while female constitute $15 \%$, this implies that rice production in the study area is not balanced between the gender. This supports the findings of [30] where 
he pointed out that in West Africa, women's involvement in rice farming varies from region to region, and even with regions. The predominance of male farming in the study area may not be unconnected with socio-cultural and religious values, in the study area. Recognition of gender roles and the specific needs of both men and women are key to effective and productive rice farming.

\subsubsection{Age Bracket}

The respondent within the age bracket of 26 to 35 years were $28.3 \%$ and $38.3 \%$ were within the age bracket of 36 to 45 years which is similar to Adam et al who reported majority of rice farmers to be within the age category of 31 to 50 years [31]. Federal Ministry of Agriculture and Rural Development reported that farmers in the age bracket of 40 years were still energetic and have a lot of positive implication for the production of rice as a crop [22]. shows that majority of the respondents are young, energetic and enterprising.

Majority of the respondents are stable and could command societal respect as majority of the respondent are married. Being married could mean that the respondents are responsible.

Priority knowledge that farms in Nigeria are largely small scaled and generally less than 5 hectares. These farms are usually small sized fragmented and scattered and not continuous land holdings and posses a great challenge to the much desire agricultural mechanization / Commercialization in Nigeria [33]. With regard to farm size hold by rice farmers in the study area, $36.7 \%$ of farmers had $<1$ hectare, $50.0 \%$ had $<2$ hectare, and $13.3 \%$ had $\geq 2$ hectares. This justify the findings stated above were only $13.3 \%$ had $\geq 2$ hectares.

Well experienced farmers have some positive implications for increased production [34]. The positive relationship between farming experience and farmers productivity suggests that farmers with a higher farming experience tends to have higher productivity than those with no or less farming experience. Similarly, Educational gives farmers the ability to perceive, interpret and respond to new information faster than their counterpart without education.

Table 2 shows the distribution of respondents' sociodemographic characteristics. As the results indicate, the distribution of rice farmers according to age categories shows that $28.3 \%$ of the respondent were within the age bracket of 26 to 35 years and $38.3 \%$ were within the age bracket of 36 to 45 years which is similar to [31] who reported majority of rice farmers to be within the age category of 31 to 50 years. As further shown in (Table 2), 85\% were male and $65 \%$ married. Findings also show that $28.3 \%$ of the respondents attended primary school, $38.3 \%$ had secondary education and $13.3 \%$ were graduates of tertiary Institutions. The low tertiary education could be an impediment to perception as education has been found to be a determinant of perception [32]. With regard to farm size, $36.7 \%$ of farmers had $<1$ hectare, $50.0 \%$ had $<2$ hectare, and $13.3 \%$ had $\geq 2$ hectares. Farmers with farming experience of more than 15 years had $10 \%, 10$ to 15 years had $31.7 \%, 6$ to 10 years had $41.7 \%$, and those with less than 6 years had $16.7 \%$.

Table 2. Demographic Characteristics of the Respondents in Dadin-Kowa.

\begin{tabular}{|c|c|c|}
\hline Variable description & Frequency (f) & Percentage $(\%)$ \\
\hline \multicolumn{3}{|l|}{ Gender } \\
\hline Male & 51 & 85.0 \\
\hline Female & 9 & 15.0 \\
\hline \multicolumn{3}{|l|}{ Age (Years) } \\
\hline $15-25$ & 9 & 15.0 \\
\hline $26-35$ & 17 & 28.3 \\
\hline $36-45$ & 23 & 38.3 \\
\hline$>46$ & 11 & 18.3 \\
\hline \multicolumn{3}{|l|}{ Marital Status } \\
\hline Single & 14 & 23.3 \\
\hline Married & 39 & 65.0 \\
\hline Divorced & 5 & 5.0 \\
\hline Separated & 4 & 6.7 \\
\hline \multicolumn{3}{|l|}{ Educational Level } \\
\hline Informal & 12 & 20.0 \\
\hline Primary education & 17 & 28.3 \\
\hline Secondary & 23 & 38.3 \\
\hline Tertiary & 8 & 13.3 \\
\hline \multicolumn{3}{|l|}{ Farm Size (In Hectare) } \\
\hline $0-0.5$ & 22 & 36.7 \\
\hline $0.6-1$ & 30 & 50.0 \\
\hline 2 and above & 8 & 13.3 \\
\hline \multicolumn{3}{|l|}{ Years of Experience } \\
\hline $0-5$ & 10 & 16.7 \\
\hline $6-10$ & 25 & 41.7 \\
\hline $10-15$ & 19 & 31.7 \\
\hline 15 and above & 6 & 10.0 \\
\hline
\end{tabular}

Source: Field Work, 2018. shows respondents' perceived effect of rainfall on rice yield. $95 \%$ respondents affirmed the occurrence of reduction and fluctuation in rainfall pattern and subsequently changes in the length of Hydrological growing season. The result however is in conformity with the findings of Egbe et al who reported that respondents are aware of alterations in climate parameters and the regularity in their manifestations [2]. The result reveals a favourable disposition by $25.0 \%$ of the respondents of rainfall variability effects on rice yield. This indicates a positive impact on rice yield while $75.0 \%$ of the respondents were unfavorably disposed to the effects of rainfall variability on rice yield, indicating a negative impact on rice yield.

Among the key findings of the Questionnaire survey are the following:

1. That the population of youths engaged in rice farming is low which could be attributed to rural-urban migration prevalence and implies loss of labour for rice production.

2. Farmers are aware of the reduction and fluctuation in rainfall pattern strongly influenced by Spirituality and personal experiences.

3. Findings also reveals that majority of the farmers are having 6 to 15 years of rice farming experience which suggests their ability to ascertain significant changes in rainfall variability.

\section{Conclusion}

This study has tried to relate the trend of mean annual rainfall records that covered a daily rainfall data for a period of seventeen (17) years with the perception of the farmers at local scale. (Dadin-kowa). The result has shown prevalence 
of rainfall variability as was confirmed by a majority of the farmers during survey whom having 6-15 years of rice farming experience, suggest their ability to ascertain significant changes in rainfall variability. In the case of rice production, result reveals that rainfall variability had adverse effect on the yield of rice in the study area. The adverse effect, though insignificant during the period of study, is a warning signal to rice stakeholders to take some precautionary measure against unfavorable effects of rain variability on rice yield.

\section{Recommendations}

A study understanding farmers' perceptions on the effect of rainfall variability on rice yield can prove extremely valuable. Furthermore, the findings and results presented here reveal some important insights and are also great sources of information for policy makers and extension workers alike. These insights lead to several important policy implications. First, a strong initiative by policy makers for planned adaptation is important. An effective climate information services can increase the success rate of adaptation and efficiency of resource use for rice production. Similarly, Future policy options needs to prioritize Sex, Age, Education and Family planning settings with Climate adaptation options.

\section{References}

[1] Adejuwon, J. O (2006). Food crop production in Nigeria. II Potential Effects of Climate Change. Clim Res.

[2] Egbe C, Aro MA, Okon AE, Bisong FE (2014). Rural Peoples' Perception of Climate Change Variability/Change in Cross River State Nigeria.

[3] Kuta, D. A (2011). Nigeria: Climate Change and Agriculture in country. Leadership (Abuja), September 18. Retrieved on March 17, 2015 from http://allafrica.com/nigeria/climate.

[4] Tsado, J. H., Ojo. M. A., Ajayi. O. J. (2014). Impact of Training the Trainers' Programme on Rive Farmers' Income and Welfare in North Cntral. Nigerian Journal of Advanced Agricultural Technologies 1 (2): 157-160.

[5] Zarakani, F., Sharafi, L., Azadi, H., Hosseininia, G., De Mayer, P., Witlox, F. (2012). Drought Vulnerability Assessment: The Case of Wheat Farmers In Western Iran. Global. Planet. Change. 2012, 98, 122-130.

[6] Adeleke, M. L., Al-Kenawy, D., Nasr-Allah, A. M., Murphy, S., El-Naggar, G. O., Dickson, M., (2018). Fish farmers' perceptions, impacts and adaptation on/of/to climate change in Africa (the case of Egypt and Nigeria). In: Theory and Practice of Climate Adaptation. Springer, Cham, pp. 269-295.

[7] Food and Agriculture Organization, (2016). AQUASTAT Website. Food and Agriculture Organisation of the United $\begin{array}{lll}\text { Nations } & \text { (FAO). } & \text { Retrieved }\end{array}$ http://www.fao.org/nr/water/aquastat/countries_regions/NGA/.

[8] Gebreyes, M., Zinyengere, N., Theodory, T. F., Speranza, C. I. (2017). Chapter 1-Introduction: grounding climate change, vulnerability, and adaptation in Africa. Beyond Agric. Impact. Mult. Perspect. Clim. Change Agric. Afr. 1-11. Retrieved from.

https://www.sciencedirect.com/science/article/pii/B978012812 6240000016 .

[9] Ochieng, J., Kirimi, L., Mathenge, M., (2016). Effects of climate variability and change on agricultural production: the case of small scale farmers in Kenya. NJAS Wagening. J. Life Sci. 77, 71-78.

[10] Thakural, L. N., Kumar, S., Jain, S. K., Ahmad, T., (2018). The impact of climate change on rainfall variability: a study in central himalayas. In: Singh, V. P., Yadav, S., Yadava, R. N. (Eds.), Climate Change Impacts. Springer Singapore, pp. 181192.

[11] IPCC, (2014). Climate Change 2014: Impacts, Adaptation, and Vulnerability. Part B: Regional Aspects. In: Contribution of Working Group II to the Fifth Assessment Report of the Intergovernmental Panel on Climate Change. Cambridge University Press.

[12] Ford, J. D., Berrang-Ford, L., Bunce, A., McKay, C., Irwin, M., Pearce, T., (2015). The status of climate change adaptation in Africa and Asia. Reg. Environ. Chang. 15 (5), 801-814.

[13] Bryan, E., Bernier, Q., Espinal, M., Ringler, C., (2017). Making climate change adaptation programmes in subSaharan Africa more gender responsive: insights from implementing organizations on the barriers and opportunities. Clim. Dev. 1-15. Retrieved from. http://www.tandfonline.com/doi/full/10.1080/17565529.2017. 1301870 .

[14] Connolly-Boutin, L., Smit, B., (2016). Climate change, food security, and livelihoods in subSaharan Africa. Reg. Environ. Chang. 16 (2), 385-399.

[15] Perez, C., Jones, E. M., Kristjanson, P., Cramer, L., Thornton, P. K., Forch, W., Barahona, C., € (2015). How resilient are farming households and communities to a changing climate in Africa? A gender-based perspective. Glob. Environ. Chang. $34,95-107$.

[16] Sonwa, D. J., Dieye, A., Mzouri, E.-H. E., Majule, A., Mugabe, F. T., Omolo, N., et al., (2017). Drivers of climate risk in African agriculture. Clim. Dev. 9 (5), 383-398. Swedish International Development Cooperation Agency (SIDA), 2015. Women and food security. Gender Tool Box (Brief).

https://www.sida.se/contentassets/bc3dc44b16c44725868e571 25b9542e3/women-and-food-security.pdf.

[17] De Souza, K., Kituyi, E., Harvey, B., Leone, M., Murali, K. S., Ford, J. D., (2015). Vulnerability to climate change in three hot spots in Africa and Asia: key issues for policy-relevant adaptation and resilience-building research. Reg. Environ.

[18] Sertoglu, K., Ugural, S., Bekun, F. V., (2017). The contribution of agricultural sector on economic growth of Nigeria. Int. J. Econ. Financ. Issues 7 (1), 547-552. Retrieved from.

http://www.econjournals.com/index.php/ijefi/article/view/394 1.

[19] Ologeh, I. O., Akarakiri, J. B., Adesina, F. A., (2018). Constraints and Limits to Climate Change Adaptation Efforts in Nigeria. Limits to Climate Change Adaptation. Springer, Cham, pp. 159-174. 
[20] Kanu, W. N., Onyekwere, I. A., Njemarize V. C. (2014) Demographic Factors and Sustainable Rice Production Among Male and Female Farmers in Rice Producing Communities of Imo State. Department of Sociology, Imo State University, Oweri, Nigeria.

[21] Adam, A. G, Bidoli, T. D, Ammani, A. A and Oduehie T. C (2018). Gender Participation in Rice Processing Value Chain in Kebbi and Sokoto States, Nigeria. Global Journals Vol 18. 2018.

[22] Federal Ministry of Agriculture and Rural Development. (FMARD). (2008) National Food Self Sufficiency. Retrieved from http: fmard.gov.ng.

[23] Onyegbula C. B and Aladeji (2017) Rice farmer's perception of the effects of climate on the development stages in Niger State. Academic journal. Vol 9. (2), pp. 14-19.

[24] Ajetumobi, J., Abiodun A., Hassan K. (2010). Economic Impact of Climate Change on Rice Agriculture in Nigeria. Trop. Subtrop. Agroecosyst. 14 (2011): 613-622.

[25] Alhassan, I., Saddiq, A. M., Gashua, A. G., Dantata, I. J. and Gwio kura, K. K. (2016). Evaluation of Irrigation Water Requirements of some Crops in Dadin-kowa Dam Irrigational Scheme of Nigeria. Gashua journal of Irrigationj and Desertification Studies, Vol. 2.

[26] Ikusemoran M., Bala B. W and Lazarus A. M. (2016). Geospatial Techniques for Terrain Analysis of Gombe State Nigeria. Journal of Geography Environment and Earth Science International (6): 1-20.

[27] Ibeje AO, Okoro B. C (2013). Short Term Forecasting of
Dadin-kowa Reservoir Inflow using Artificial Neural Network. IJES. 63-73.

[28] NIMET, 2016. 2016 Seasonal Rainfall Prediction (SRP). Retreived from. Nimet.gov.ng/sites/default/files/publications/2016\%20SRP.pdf . NIMET (Nigerian Meteorological Agency), 2011. Nigeria Climate Review Bulletin. NIMET, Nigeria. Retrieved from. http://www.nimetng.org/uploads/publication/NIMET\%20clim ate $\% 20$ review\%0PDF\%202011\%20(1).pdf.

[29] NIMET (Nigerian Meteorological Agency), 2017. 2017 Seasonal Rainfall Prediction (SRP). Retrieved from. http://www.nimet.gov.ng/sites/default/files/publications/NiMet $\%$ 202017\%20SRP 2.pdf.

[30] Hovio, T. (2007). Women's Role In Rice Farming. FAO Women and Population Division. Rome, pp. 1-9.

[31] Arimi, K. (2014). Determinants of Climate Change Adaptation Strategies used by Rice Farmers in South-Western Nigeria. $J$. Agric. Rural Dev. Trop. Subtrop. 115 (2): 91-99.

[32] Ajibola, A. O (2014). Climate Change Effect on Household Agric-Economy and Adaptative responses among Agricultural Households in Nigeria. Contribution Paper Presentation at the Centre for the Study of African Economies at St. Caterine's College, Oxford University UK. 23-25 March.

[33] WARDA (2008) Africa Rice Trends 2007. Africa Rice Center (WARDA), Cotonou, Benin.

[34] Nwoye, M. (2007). Gender Responsive Entrepreneurial Economy of Nigeria Enabling Women in a Disabling Environment. A Monograph. Pp. 12. 